\title{
The Importance of a Surface Layer of a Cast Iron Casting in the Design of Technological Processes
}

\author{
Piotr Kuryło*, Władysław Papacz, Edward Tertel
}

University of Zielona Góra, Faculty of Mechanical Engineering, Institute of Mechanical Engineering and Machine Operation, 65-001 Zielona Góra, Licealna 9 street, Poland

\begin{abstract}
The paper defines the scope and character of the surface layer of castings made of selected types of cast iron with special consideration of on spheroidal cast iron. The study also showed that on the basis of the distribution of hardness along the casting core, it is possible to define the distribution of structures and the reach of the surface layer of a cast iron casting.
\end{abstract}

Keywords: Surface layer, reaction zone, transition zone, hardness.

\section{Introduction}

Surface layers have been the subject of research of many scientific centres in the world for many years. Warstwa wierzchnia od wielu lat była i jest tematyką badawczą wielu ośrodków naukowych na świecie. Issues connected with the surface layer of a cast are related to tribology. The surface and the sub-surface parts of a half-product, which is intended or not to be subject of further processing, have been treated marginally so far. Conditions in which a half-product is manufactured influence essentially its properties, especially in its subsurface zone and in the core of the casting. Having investigated cast iron castings made of grey cast iron and lamellar graphite, the author found a characteristic distribution of the properties of the surface layer of the examined castings, particularly for raw castings, along the direction from the surface into the inside of the product. A surface layer is a material layer limited by an outer (real) surface of an object (product) containing this surface and such part of material inside it which present modified physical and sometimes chemical properties in relation to the remaining material of the object (material of the core ) [3].

The surface layer of a raw casting made of cast iron includes an oxide layer and glass-like materials - a reaction zone - mistakenly called an epidermis and a transition zone. The depth of the surface layer and its character depend on the conditions in which the product was manufactured. Characteristic properties, such as distributions of hardness, microhardness, stresses, and structure, follow the guidelines described in the European Standards. A model of a surface layer of grey cast iron of a flake graphite structure, basing on typical hardness distributions is presented in Fig. 1.

Fig. 2, in turn, shows the stress distribution against the hardness distribution. It should be stated that a surface layer of grey cast iron is best represented by hardness distribution in the cross-section of the wall of a casting.

Various research centers have carried out wear and tear tests which relate to the surface formed within the transition zone of the surface layer of gray cast iron for the following parts: 
$\checkmark \quad$ parts for agricultural machinery,

$\checkmark$ forms and pre-forms for glass moulds,

$\checkmark$ pomp parts,

$\checkmark$ parts for mining machinery.

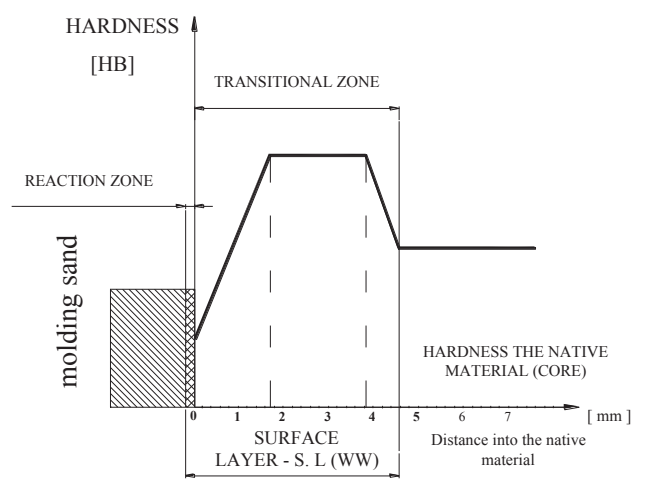

Fig. 1: A model of a surface layer of grey cast iron with flake graphite, basing on hardness and structure distributions [3].

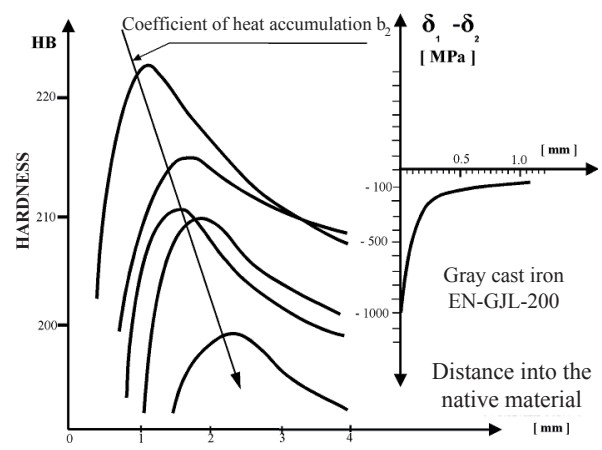

Fig. 2: Hardness distribution in the cross-section of the casting made of grey iron cast with flake graphite in relation to the casting's heat accumulation coefficient b2 [3;4].

The investigation of gray cast iron EN-GJL-250 and EN-GJL-200 resulted in the conclusion that there are no contraindications to use the transition zone of the surface layer of the cast as an exploitation area of the product.

The characteristics of the cast resulting from the wall thickness and the thermo-physical conditions, i.e. the heat accumulation coefficient of the form, determine the hardness of the surface layer in the cross-section of the wall and other parameters. Increasing the hardness of the exploitation surface of the product within the transition zone will allow the improvement of the quality of its working surface. It is possible to reduce the technological allowances and even to obtain a product with dimensions as close as possible to its design requirements. The selected areas can be finally machined in the range of 0.5 $\div 1 \mathrm{~mm}$ by removing only the transition zone by e.g. grinding.

Fig. 3 shows the abrasiveness of grey cast iron EN-GJL-200. The graph shows beneficial effects of the transition zone of the surface layer of grey cast iron with flake graphite on the formation of a product operating area within its range. Tests were carried out at the friction velocity of $v=1.05 \mathrm{~m} / \mathrm{s}$ and the pressure of the sample onto the steel counterbody amounting 0,5 MPa even in the case of dry friction.

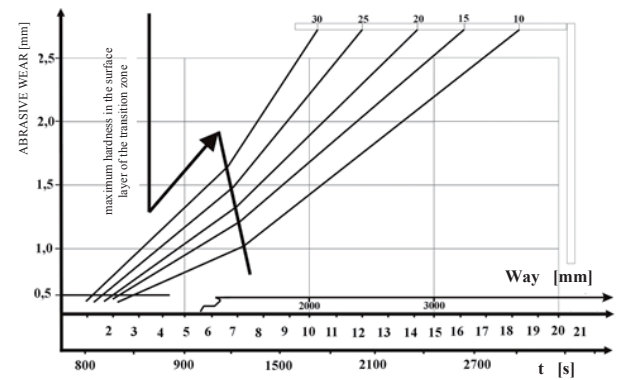

Fig. 3: Friction wear of grey cast iron 200 in the function of time and distance [3].

Recently, numerous global cast iron manufacturers have changed their production profile from cast iron of a flake graphite structure into the production using grey cast iron. The special form of the spheroidal graphite makes it a material of future wide use.

Production of ductile iron castings in Poland and abroad continues to grow and whereas the production volume stabilized in Western Europe and represents 50\% to $60 \%$ of the total production of cast iron, in Poland it remaines at a much lower level, thus in 1993 it was 9,6\% [11], in 1999 it was $12,0 \%$, and in 2001 it was just $14 \%[2,12]$.

Fig. 4 shows the trends in the production of castings in $2002 \div 2011$ in Poland and abroad.

China, the US and Japan have been the unquestioned leaders in the production of castings (including cast iron) (Fig. 5) in the current decade.

Despite the global crisis an increase in the production of castings has been observed, which 


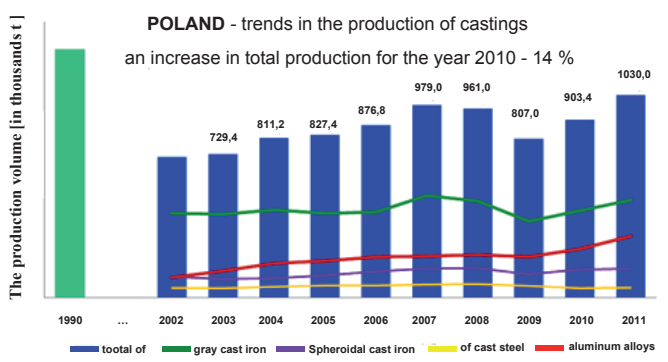

Fig. 4: Trends in the production of castings in $2002 \div 2011$ in Poland and abroad [12].

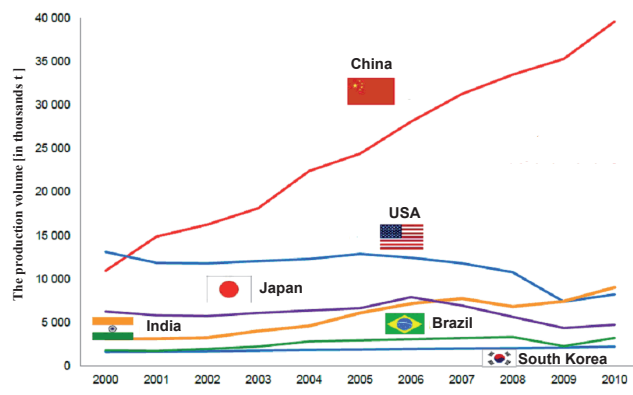

Fig. 5: Global trends in the production of castings by main producers in $2002 \div 2011[2,12]$.

was mainly generated by an increase in the production of grey cast iron and aluminum alloys for the automotive industry.

A total 14 per cent increase in the production of castings in Poland was observed, which included $[12,13]$ :

- in the production of iron alloy castings - 9\%

- grey cast iron and alloy cast iron castings - 12\%

- ductile iron castings - 3\%

- in the production of iron alloy castings nonferrous - $25 \%$

- aluminum alloy castings - $27 \%$

- magnesium alloy castings - $20 \%$

It should also be noted that 14 per cent increase in the production of castings compared to 2010 ranks Poland at the seventh position among the manufacturers of castings in Europe (sixth in the countries of the European Union), fifth in production of castings from non-ferrous alloys (fourth in the EU). Also it is worth mentioning that Poland is experiencing a considerable increase in productivity by 15\% compared to 2011 and a significant increase in exports of castings to the level of $60 \%$.
Estimated market share of recipients of castings in Poland in 2011 is shown in Fig. 6 [12, 13].

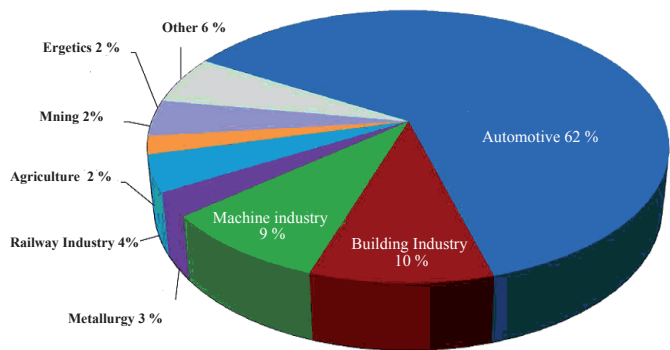

Fig. 6: Estimated market share of recipients of castings in Poland in 2011 [2;12, 13].

\section{Objective and Scope of Research}

The primary objective of the study was to confirm the assumption that all hypotheses regarding high-quality iron made of flake graphite also apply to high-quality spheroidal cast iron. Thus, the conducted studies were to determine the range and form of a surface layer of selected types of castings made of cast iron in order to demonstrate its usability for shaping (within its range) exploitation surfaces. The issue is also associated with a decrease in technological allowances and thus an increase in yield. Fig. 7 shows diagrams of hardness distribution of castings as a function of distance from the surface of a raw casting towards the core of the casting for the three selected types of grey cast iron, i.e. ductile iron.

The diagram reveals a stabilization of the hardness of the native material (the core cast) of the wall of the casting in the range of 1,2 to $2 \mathrm{~mm}$. The lines showing the processes of solidification and cooling of the walls (of a thickness up to 10 $\mathrm{mm}$ ) do not follow characteristic shapes and the maximum of the hardness of the surface layer falls, in this case, in the centre of the core of the casting, i.e. in the wall of the casting along its heat axis (castings with such thick walls are generally not subject to further processing). The analysis of the examined distribution of hardness on the cross-section of ductile iron castings (GJS-500-7) alows the following statement:

- the hardness of the casting surface depends on the cooling conditions of the form and also on the hardness of the reaction zone of the surface 


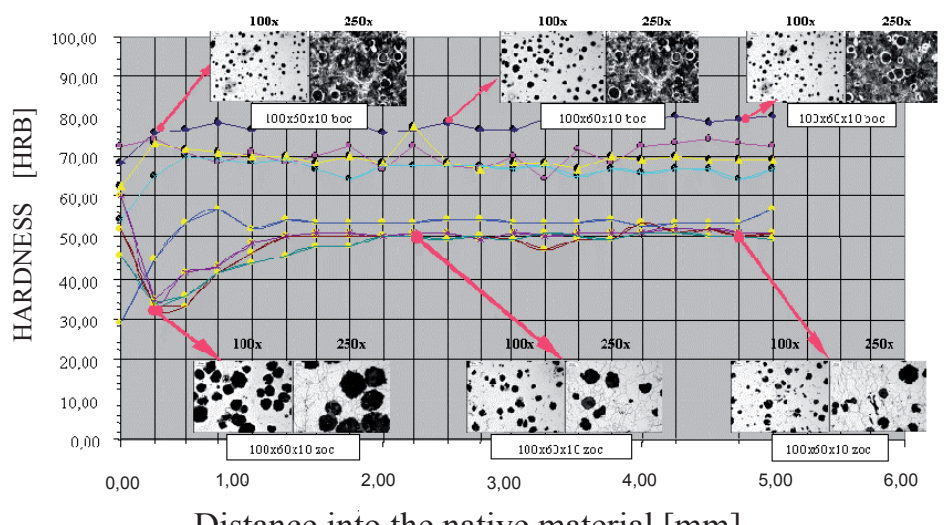

Distance into the native material $[\mathrm{mm}]$

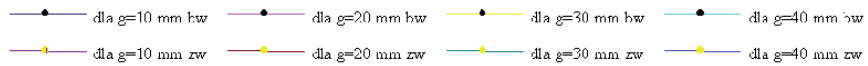

Fig. 7: Hardness of a casting in the function of distance from the surface of a raw casting, with photographs of metallographic structures for each characteristic depth for ductile iron GJS-500-7 [7].

layer-a zone the composition of which depends, inter alia, on the predisposition of the material of the casting to react chemically with molten cast iron [1],

- hardness distribution on the cross-section of the wall of a cast iron is conditioned by the cooling properties of the moulding compound and on the thickness of the wall of a casting [3,5],

- the hardness of the transition zone lof the surface layer of a ductile iron casting) increases towards the inside of the casting until it reaches a stable level at the core of the cast (original material).

The presented exemplary distribution confirms the results of the introductory studies. The distribution manifests a decrease in the maximum hardness in the surface layer depending on the decrease in the coefficient of heat accumulation b2 of a moulding compound (not included in this study). It also manifests the shift in the maximum hardness of the surface layer into the casting inside and vice versa.

In order to make a good use of the research conclusions, it seems to be advisable to apply Rockwell's method as an authoritative measure for the determination of the scope and the course of the surface layer of the raw casting, as it is a resultant hardness of particular structures of ductile iron (averaged hardness of individual structures).

The surface layer of the raw casting made of ductile cast iron manifests a variable hardness and a different structure in relation to the core material.

In this aspect the following general conclusions may be drawn:

- Various moulding compounds, characterized by different thermal physical properties result in the formation of particular surface layers of a raw casting [3],

- The application of moulding compounds of higher heat accumulation coefficients results in the reduction of the thickness of the surface layer of a raw casting, and, simultaneously, the increase in the hardness of the layer [3],

- The alteration of the wall thickness of a casting causes a change in the structure and the hardness of the surface layer of raw casting of cast iron $[1,3]$,

- The increased hardness of the machined surface will allow the increase in the performance properties of the finished product,

- The use of the characteristics of the surface layer of ductile cast iron, will help to reduce technological allowances,

- In the design of a technological process of manufacturing products made of ductile iron, the form and the range of the surface layer of the casting should be taken into account in order to obtain a product of as high quality as possible at minimum costs.

The walls of iron castings are generally of various 
thickness. Thus, it is recommended to carry out studies on different moulding compounds in the function of wall thickness, in order to determine the possibility of clotting process control in order to obtain the required structure of the surface layer of the raw casting, as well as to obtain the required hardness distribution.

\section{References}

[1] Bechný L.: Erhühung der Quality gegossener Werkstoffe durch die Schmelzfiltration, Berichte Praxis HTW Dresden 1-95, s. 31

[2] Dobrzański L. A.: Podstawy nauki o materiałach i metaloznawstwie. Materiały inżynierskie z podstawami projektowania materiałowego. WNT Warszawa 2002.

[3] Janik S.: Zmiany wybranych wskaźników skrawalności warstwy

[4] wierzchniej odlewów z żeliwa szarego wykonanych w różnych

[5] masach formierskich, Praca doktorska, Politechnika Poznańska 1978.

[6] Janik S., Wieczorowski K., Rozkład twardości w warstwie wierzchniej surowych odlewów z ZL250, IV Og. Konf. N-T, Zielona Góra, 1979.

[7] Janik S., Wybrane własności warstwy wierzchniej odlewu żeliwnego, XIII Symp. Tribolog., Częstochowa - Poraj, 1984.

[8] Janik S., Wieczorowski K., Wykorzystanie właściwości strefy przejściowej warstwy wierzchniej odlewu żeliwnego dla podwyższenie własności eksploatacyjnych wyrobu, V Konf. N-T, Politechnika Rzeszowska, Rzeszów, 1995.

[9] Kuryło P.: Badania właściwości technologicznych i eksploatacyjnych warstwy wierzchniej odlewu z żeliwa sferoidalnego; Praca doktorska, Politechnika Poznańska, Poznań 2003.

[10] Prace Instytutu Odlewnictwa zeszyt 1-2. Seminarium pt." Odlewnictwo w Polsce i na Świecie". Biuletyn instytutu odlewnictwa - Kraków 1998.1/98

[11] Podrzucki Cz:: Żeliwo- struktura, właściwości, zastosowanie, wyd. ZG STOP, tom 1, Kraków 1991

[12] Przegląd Odlewnictwa 7/97 Jerzy Piaskowski, Pięćdziesiąt lat żeliwa sferoidalnego w polskim odlewnictwie]

[13] Przegląd Odlewnictwa 1/2001 wg. Ministry of International Trade and Industry, Yearbook of Machinery Statistics and Yearbook of Iron and Steel Statistics. Wydawnictwo: Annual Statistics of Materials - processing Industries of Japan, 1999. The Sokeizai Center.

[14] Sobczak J. Prognozy i trendy rozwojowe w odlewniach światowych i krajowych. Praca zbiorowa. Wyd. Instytut Odlewnictwa w Krakowie. Kraków 2012.

[15] Tabor A. Polskie urządzenia do ekologicznej produkcji żeliwa sferoidalnego. Nasza Politechnika. Dwumiesięcznik. Gazeta Politechniki Krakowskiej. Nr 3.

[16] Ferdinandy, M., Lofaj, F., Dusza, J., Kottfer, D.: Príprava a vlastnosti vrstiev WCC. In: Acta Mechanica Slovaca. Roč. 12, č. 4-B (2008), s. 96-100.

\section{Biographical notes}

PhD eng. Piotr Kurylo was born in 1966 in Zielona Góra, Lecturer at University of Zielona Góra. Assistant Professor in Faculty of Mechanical Engineering University of Zielona Góra. Completed his doctorate (2003) at the University of Poznan University of Technology. Member of the Faculty of Mechanical Engineering. Specialist professional engineering, engineering of the surface layer, automation and robotics, manufacturing technologies.

doc eng. Wladyslaw Papacz, PhD born in 1961. Since 2001 he works on the Faculty of Mechanical Engineering, University of Zielona Góra as an assistant professor. He is graduated on Faculty of construction and operation of machines. His scientific and research work focused on the field of optimization and development of polymer composites structures. Member of Central European Composite Claster and Polish Scientific Society of Motorization. He directed and he worked in several European projects.

PhD eng. Edward Tertel was born in 1970 in Zagan, Poland. Since 2003 he works on the Faculty of Mechanical Engineering, University of Zielona Góra as an assistant professor. In 2003 he gained PhD in the field of mechanics at the Faculty of Mechanical Engineering and Management, Poznan University of Technology. He is an author or co-author of publications in domestic and foreign journals and conference proceedings. His research work is focused on analyses of elastic-plastic stability and optimization of sandwich structures. Member of Polish Society of Theoretical and Applied Mechanics and Polish Society of Production Management 